доктор педагогічних наук, професор

(Житомирський державний університет імені Івана Франка) dubasenyukeukr. net

ORCID: 0000-0002-9447-4527

\title{
КОНЦЕПТУАЛЬНІ МОДЕЛІ ПРОФЕСІЙНО-ПЕДАГОГІЧНОЇ ПІДГОТОВКИ МАЙБУТНІХ ПЕДАГОГІВ, РЕАЛІЗОВАНІ У ДІЯЛЬНОСТІ ЖИТОМИРСЬКОЇ НАУКОВОЇ ШКОЛИ
}

У статті обтрунтовано роль наукових шкіл у системі вищооі освіти, проаналізовано їх сутність, виділено ознаки наукової школи. Представлено результати 30-ти річної діяльності Житомирської науково-педагогічної школи на етапі концептуалізації наукових знань. У діяльності школи реалізовано наступні принципи: науковості, системності, спадкоємності, неперервності, активності, інтегративності. Представлено різноманітні конщептуальні моделі професійно-педагогічної підготовки майбутнього вчителя (когнітивна, системна, компетентнісна, ступенева), щзо розроблені у межах Житомирської наукової иколи, проаналізовано їх результативність та перспективність.

Ключові слова: наукова школа, Житомирська науково-педагогічна школа, конщептуальні моделі дослідження, професійно-педагогічна підготовка.

Постановка проблеми у загальному вигляді та ї̈ зв'язок із важливими науковими і практичними завданнями. Сучасна наука стрімко розвивається, постійно з'являються нові перспективні напрями та спеціальності, зростає обсяг наукових публікацій, за деякими даними, вони подвоюється кожні 10-15 років. У процесі прискореного розвитку наук велику роль відіграють наукові школи. Проте нинішня соціальна ситуація характеризується зниженням у суспільстві інтересу до науки, втратою престижності наукового знання і відтоком перспективних наукових кадрів за кордон та в інші сфери діяльності. Такий стан вимагає підвищення уваги до проблем наукової освіти, наукових шкіл. Також з'ясовано, що традиційні підходи до професійної підготовки фахівців не забезпечують належного формування спрямованості особистості на наукову діяльність. Виникає суперечність між сучасними вимогами до розвитку науки, підготовки майбутніх педагогів-дослідників та відсутність умов для їх реалізації; між необхідністю виховання нової генерації педагогів-дослідників, наукових працівників і недостатньою розробленістю концептуальних та методичних засад їх підготовки до роботи 3 молоддю, орієнтованої на дослідницьку діяльність.

Аналіз основних досліджень і публікацій із зазначеної проблеми. Учені зазначають, що в науковій літературі систематизовано певні напрацювання з питань діяльності наукових шкіл у закладах вищої освіти. Особливу цінність з огляду на порушену проблему мають філософські та наукознавчі праці, які закладають теоретико-методологічне підгрунтя дослідження наукових шкіл. Важливе значення у з'ясуванні сутності поняття "наукова школа", іiі характерних ознак мають роботи наукознавців П. К. Анохіна, І. А. Аршавського, В. А. Гасілова, О. А. Гнізділової, В. А. Горського, Г. М. Доброва, Б. М. Кедрова, І. Лакатоса, В. К. Криворученко, К. Ланге, С. Р. Микулінського, Н .Й. Родного, Д. Прайса, М. М. Семенова, С. Д. Хайтуна, Г. Штейнера, М. Г. Ярошевського.

Від звичайних формальних наукових колективів наукові школи відрізняються тим, що $\epsilon$ добровільними неформальними об'єднаннями, які групуються навколо "природного лідера" - знаного вченого, автора оригінальних ідей, реалізованих у дослідницькій програмі. Термін "наукова школа" вживається в двох випадках, як: 1) загальні погляди, ідеї та інтереси, що об'єднують учених, і призводять до тісної співпраці, які дають змогу залучати нові молоді таланти і на багато років визначати шляхи i темпи розвитку перспективних галузей науки; 2) невеликий науковий колектив, об'єднаний організаційно, конкретною темою, загальною системою поглядів, інтересів і традицій, які накопичуються i розвиваються при зміні наукових поколінь. Дослідники виділяють наступні ознаки наукової школи: спільність наукових інтересів і значимість дослідження; високий рівень наукових результатів і визнання школи. Наукові школи постають осередками найбільш інтенсивної концентрації творчої енергії, активно впливаючи на науковий прогрес країни [1: 86].

Наукова школа за своєю суттю являє собою ефективну модель освіти, що транслює культурні норми і цінності наукової спільноти від старшого покоління до молодшого. Перевага наукових шкіл полягає в тому, що вони "прив'язують" науку до реалій життя, мають виражений практикоорієнтований підхід. Видатний учений В. І. Вернадський зазначав: "...розвиток наукової думки знаходиться в тісному i нерозривному зв'язку з народним побутом і громадськими установами - iї розвиток відбувається в складній гущі історичного життя ..." [2: 63].

Житомирська науково-педагогічної школа "Професійно-педагогічна діяльність майбутніх учителів" була створена у 1988 році, пройшла певні етапи становлення та розвитку наукового колективу: 1) аналітико-пошуковий; 2) диференціації наукових знань; 3) систематизації та узагальнення; 
4) концептуалізації наукових знань. Наукова школа відіграла значну роль в активізації творчого потенціалу викладачів педагогічних кафедр Житомирського державного педагогічного інституту імені Івана Франка, пізніше Житомирського державного університету імені Івана Франка та закладів вищої освіти різних регіонів України. Як наслідок, відбулося взаємне потенціювання і збагачення творчого потенціалу та розвиток креативного мислення викладачів, які виділили пріоритетні напрями власного наукового пошуку, набули професійної та наукової компетентності, розвинули особистісні якості, креативні здібності, зокрема підвищився рівень їх самостійності, упевненості у своїх силах, обізнаності у наукових проблемах, у теорії та методики науково-дослідної діяльності $[3 ; 4 ; 5]$.

Житомирська науково-педагогічної школа реалізує основні теоретико-методологічні засади, нагромаджений досвід що представлено в діяльності зарубіжних та вітчизняних науково-педагогічних шкіл (В. Г. Кремень, Т. Левовицький, С. Мешальський, С. У. Гончаренко, І. А. Зязюн, Н. Г. Ничкало, П. Ю. Саух та ін.) [6].

У діяльності школи втілено наступні принципи: науковості, системності, спадкоємності, активності, інтегративності. Принциип науковості доводить необхідність здобуття наукової освіти для сучасного дослідника і постає важливим чинником розвитку творчого наукового мислення, креативності фахівця. Принции системності дає змогу розглядати будь-яке явище у взаємозв'язку з іншими явищами і процесами. У межах школи цей принцип реалізується у дослідженні комплексної проблеми "Професійно-педагогічна підготовка майбутніх учителів". За період існування школи систематизовано різноманітні моделі такої підготовки. Принцип спадкоємності та неперервності освіти, професійної спрямованості реалізовано у наступності різних поколінь науковців, коли знання, уміння передавалися від старшого до молодшого покоління вчених. Молоді дослідники, які набували певного рівня наукової компетентності, досвіду, захищали кандидатські дисертації, а далі частина з них здобували і докторську ступінь. Учені - доктори наук продовжували активно працювати, згуртовували біля себе досвідчених педагогів, талановиту молодь, транслюючи їм свій досвід, залучаючи до розробки актуальних наукових проблем і таким чином продовжується безперервний процес розвитку наукового знання. Прикладом $є$ створення двох дочірніх шкіл у межах основної науково-педагогічної школи. Принции активності, ініціативи сприяє взаємному потенціювання творчого потенціалу дослідників. Керівник школи постає генератором ідей, постійно надихаючи колег на творчу діяльність. Досвідчені науковці виступають активаторами й ініціаторами різних ідей, проектів, творчих починань, прилучаючи до наукових розвідок інших дослідників та молодь. Принщии інтегративності передбачає постійну взаємодію науковців 3 метою вирішення актуальних наукових проблем. Цей процес відбувається у науково-дослідних центрах, лабораторіях школи, де об'єднуються і співпрацюють різні покоління науковців, які цілеспрямовано діють 3 метою вирішення нагальних професійно орієнтованих проблем. Відтак, діяльність наукової школи сприяла отриманню і розвитку наукової обізнаності викладачів, які пройшли аспірантуру, а частина і докторантуру та продовжують постійно поповнювати свої знання, розвивати дослідницькі вміння та навички. Наукова освіта виступає теоретико-методологічним підгрунтям діяльності викладача вищої школи, що підвищує рівень його професіоналізму та педагогічної майстерності. Сучасний викладач має бути взірцем відданості науці, постійним активатором та реалізатором креативних ідей, стимулюючи і студентів до творчої, пошукової діяльності [7].

У межах Житомирської науково-педагогічної школи розроблено різноманітні концептуальні моделі професійної освіти майбутнього вчителя. При цьому метод моделювання окреслений нами як один із провідних дослідницьких методів, спрямований на розвиток особистісного і професійного потенціалу майбутнього вчителя, ураховуючи світові та вітчизняні здобутки. Модель професійно-педагогічної підготовки майбутнього вчителя за В. І. Міхєєвим може бути представлена в єдності кількох аспектів ііі застосування [8], а саме гносеологічного, за яким окреслена модель постає як елемент процесу пізнання досліджуваного педагогічного явища; загальнометодологічного, що передбачає необхідність оцінювати зв'язки i відношення як між компонентами професійно-педагогічної освіти (когнітивним, компетентністним, аксіологічним та ін.), так і між характеристиками стану їх сформованості у процесі безперервного розвитку.

Мета дослідження: на основі вивчення 30-ти річної діяльності Житомирської науково-педагогічної школи "Професійно-педагогічна діяльність майбутніх учителів", що грунтується на освоєнні світового та вітчизняного досвіду у цій сфері, проаналізувати значущі результати іiі роботи, які представлено у вигляді розроблених науковцями школи концептуальних моделей професійно-педагогічної підготовки (когнітивну, системну, компетентнісну, ступеневу).

До основних методів дослідження віднесено: аналіз, синтез, моделювання, систематизації, класифікація, порівняння та ін.

Виклад основного матеріалу 3 обгрунтуванням отриманих наукових результатів. Проведений аналіз діяльності Житомирської науково-педагогічної школи на концептуальному етапі ії розвитку дав змогу виокремити концептуальні моделі професійно-педагогічної підготовки майбутніх учителів, виходячи з ії структури - когнітивну, системну, компетентнісну, ступеневу. 
Когнітивна модель відображає установку дослідників на домінування інтелектуальних процесів у професійно-педагогічній підготовці майбутнього вчителя. Будь-яка пізнавальна діяльність - педагогічна, соціальна, економічна - потребує виокремлення й опрацювання індивідом інформації при розв'язанні пізнавальних професійно-орієнтованих задач, спрямованих на стимулювання його пізнавальнопрофесійної активності. Формування когнітивних схем залежать від віку, освіченості, індивідуальнопсихологічних особливостей, характеру професійної діяльності. Їх слід розглядати як внутрішні психолого-педагогічні умови, що впливають на процес і успішне виконання тієї чи іншої пізнавальнопрофесійної діяльності. Диференціацію когнітивної сфери як необхідний фактор здійснення успішної діяльності відзначали такі сучасні педагоги та психологи, як О. О. Бодальов, А. Олах, В. А. Романець, С. М. Єфіменко, С. О. Сисоєва. Останніми десятиріччями здійснено низку досліджень, присвячених підготовці вчителя до творчого розв’язання складних задач педагогічного процесу (І. В. Алексашина, Н. В. Гузій, Л. У. Ведернікова, Н. В. Кічук, Л. В. Кондрашова, Ю. Н. Кулюткін, В. О. Сластьонін, Н. С. Щуркова), що базується в основному на формуванні у студентів творчого ставлення до педагогічної праці, творчого стилю діяльності. С. Ю. Тєміна розглядає проблему пошуку нестандартного рішення педагогічної ситуації на основі використання класифікації педагогічних ситуацій і застосування евристичних методів до розв'язання педагогічних задач. Під педагогічною задачею науковці розуміють усвідомлене суб'єктом педагогічної діяльності цілей навчально-виховної роботи, комплексу умов цієї роботи і проблем, що виникають. Водночас педагогічна задача - це "результат усвідомлення суб'єктом виховання в педагогічній ситуації необхідності виконання професійних дій і прийняття їх до виконання" (Н.В.Кузьміна, Л. Ф. Спірін, М. Д. Степінській, М. Л. Фрумкін). Проблема задачі - це результат усвідомлення суперечності між відомою метою роботи і невідомими шляхами іiі досягнення. Важливу роль у професійному становленні вчителя професіонала має його підготовка до вирішення багатоманітних педагогічних задач, які складають підгрунтя майбутньої педагогічної діяльності. Найбільш ефективний шлях навчання студентів процесу моделювання при розв'язанні задач - це підбір типових ситуації, таких, що зустрічаються в практиці та самостійне складання педагогічних задач. Тому особливу актуальність набуває розробка типології (класифікації) педагогічних задач як вирішальної передумови формування у студентів культури розв'язання навчально-виховних задач (О. А. Дубасенюк). Відомо, що педагогічна задача усвідомлюється як задача у випадку, якщо у діяльності педагога виникає утруднення, яке можна вирішити декількома способами, обравши найбільш оптимальний в конкретних умовах. Таким чином, на основі розглянутих типологій (навчальних, навчально-пізнавальних, навчальнопедагогічних, виховних, управлінських педагогічних задач) запропоновано загальна типологія професійно орієнтованих педагогічних задач [9: 100-103].

I. Професійно-оріснтовані педагогічні задачі, які відображають зміст курсу "Педагогіка":

1. Задачі, спрямовані на осмислення студентами загальних основ педагогіки: предмету, мети і завдань курсу; сутності базових категорій педагогіки; особливостей світу дитинства, отроцтва, юнацтва; узагальнення різноманітних педагогічних явищ і процесів, взаємозв'язки педагогіки з суміжними дисциплінами, що взаємно збагачує людинознавчі науки; визначення специфіки методів науковопедагогічного дослідження та їх оволодіння; усвідомлення відмінностей педагогічної професії, функцій педагога в сучасному суспільстві; соціальної відповідальності учителя за долю майбутнього покоління; значення самоосвіти та самовиховання вчителя у педагогічній діяльності.

2. Задачі, які допомагають осягнути: сутність базових категорій "Дидактики", процесу навчання, змісту освіти в сучасній школі; специфіку методів та засобів навчання; різноманітність форм організації навчання; специфіку уроку як основної форми співпраці суб'єктів освіти; особливості методичної роботи в школі.

3. Задачі, які сприяють усвідомленню: сутності базових категорій "Теорії та методики виховання", процесу виховання, його структурних елементів; основних напрямів виховної діяльності, а також мети, змісту, форм та методів виховання особистості та колективу; організаційно-педагогічних засад роботи класного керівника, особливостей індивідуальної роботи з учнями, педагогічних основ громадських організацій дітей та підлітків.

4. Задачі, які допомагають осмислити: наукові засади управління загальноосвітніми навчальними закладами; особливості внутрішньошкільного керівництва і контролю; специфіку методичної роботи в школі; сприяють вивченню і впровадженню передового педагогічного досвіду.

ІІ. Професійно оріснтовані педагогічні задачі у закладах вищої освіти на основі аналізу наукової педагогічної літератури та розробленої типології виховних задач, можна поділити ще на два класи задач: 1) за логікою; 2) за етапами педагогічного процесу. 3 позиції загальної теорії функціональних задач (П. К. Анохін, Б. Ф. Ломов, К. В. Судакова та ін.) професійна діяльність, основною мотивацією якої виступають постановка і вирішення особистісно значимої професійної проблеми, що може вміщувати низку задач. Вивчаючи закони розвитку поведінки людини, Б. Ф. Ломов виділяє її важливу складову антиципацію (передбачення перебігу подій). У зв'язку з цим - актуалізуються процеси цілеутворення і формування плану дій. При цьому більшість задач набувають ймовірного характеру, бо значна кількість 
педагогічних феноменів, явищ за своєю природою, не є жорстко детермінованими, а підпорядковані впливу випадкових і невипадкових чинників, тому можливе застосування ймовірнісного підходу до діяльності вчителя. На основі такого підходу розробляються засоби та умови ефективного розв'язання педагогічних задач.

Наступний варіант когнітивної моделі представлено у дослідженні І. І. Коновальчука, яким розроблено концептуально-змістову модель технології реалізації інновацій у загальноосвітніх навчальних закладах, що відображає мету, теоретико-методологічні засади, послідовність етапів концептуалізації, адаптації, безпосередньої реалізації, активного продуктивного використання і розвитку нововведення та деталізує зміст інноваційних змін у педагогічній системі. У змістовому аспекті технологія реалізації інновації - це процесуально структурована послідовність етапів, форм, методів, прийомів, засобів спрямованих на вивчення, актуалізацію та оптимізацію практичного використання нововведень, що передбачає конкретизацію закономірностей та принципів інноваційних процесів й уточнює тактику реалізації освітніх інновацій у навчально-виховному закладі з урахуванням наявних умов і ресурсів. Основне функціональне призначення технології полягає у відтворенні інновацій та забезпеченні можливості їх використання в масовій педагогічній практиці. Автором запропонована технологія проведення експертизи освітніх інновацій для аналізу, оцінювання, класифікації, прогнозування особливостей упровадження та можливих результатів нововведень відповідно до певних норм [10].

Системні моделі дослідження. Вони достатньо поширені у дослідженні науковців школи.

Так, О. С. Антоновою на основі аналізу стану дослідженості проблеми обдарованості особистості у філософській, соціологічній, історичній, психолого-педагогічній літературі обгрунтовано сукупність вихідних положень, що складають теоретико-методологічні засади іiі вирішення. Визначено, що системотвірним чинником у дослідженні феномена обдарованості виступає особистість як сукупність особистісних якостей, що має ієрархічну побудову і включає ряд підсистем, системний аналіз яких дозволяє описати iї як організовану цілісність, визначити місце і роль здібностей та обдарованості в цій системі. При цьому виявлено взаємозв'язки між компонентами різного порядку, відокремлено суттєве від випадкового. Модель обдарованості побудована на основі концепції тривимірної, поетапно конкретизованої психологічної структури особистості, розробленої українським ученим В.В. Рибалкою. На цій основі О.Є. Антоновою запропоновано модель педагогічно обдарованої особистості, що вміщують такі компоненти: педагогічні здібності, рівень розвитку яких вище за середній; педагогічна креативність, або здатність до педагогічної творчості; педагогічне покликання, як спрямованість особистості до виконання педагогічної діяльності; інтелектуальні здібності, як необхідний чинник, що сприяє засвоєнню та трансформації знань у визначеній науковій сфері. Представлено основні параметри, що характеризують компоненти педагогічної обдарованості, визначено критерії їх оцінювання, описано рівні розвитку їх у майбутніх педагогів. Відповідно до моделі розроблено концепцію навчання обдарованих майбутніх учителів, яка реалізована у практичній підготовці студентів шляхом створення умов для творчого, інтелектуального, духовного і фізичного розвитку особистості. Отже, запропонована концепція інтегрує ознаки когнітивної та системної моделей дослідження [11].

Н. Г. Сидорчук моделювання системи професійно-педагогічної підготовки студентів університетів здійснено з урахуванням євроінтеграційних процесів та одного 3 варіантів системних моделей, які будуються, в основному на базі фізичних законів і гіпотез відповідно до структури системи та ймовірності ii подальшого функціонування. Саме системні моделі постають ядром процесу моделювання. Їх метою є визначення рівня абстрактного опису системи, або рівня конкретизації іiі подання через сукупність властивостей змодельованої системи. Модель і система знаходяться в певних відношеннях, від яких залежить міра відповідності між ними, що визначається поняттям ізоморфізму та гомоморфізму. Система та модель є ізоморфними, якщо існує взаємно однозначна відповідність між ними, завдяки якій можна перетворити одне представлення на інше. Строго доведений ізоморфізм для систем різної природи дає змогу переносити знання з однієї галузі в іншу. На основі теорії ізоморфізму дозволено не тільки створювати моделі систем і процесів, але й організовувати процес моделювання [12].

В основу моделювання системи професійно-педагогічної підготовки студентів університетів в умовах євроінтеграційних процесів, Н. Г. Сидорчук запропоновано нове математичне поняття "багатошарової моделі", що вміщує багатофункціональні площини. Такі моделі представлені у вигляді сендвіч-моделей $(\mathrm{CM})$, які являють собою площини, що відповідають функціональним складовим досліджуваного явища та вміщують певні елементи і зв'язки між ними. Кожна площина СМ розглядається як самостійна модель ряду складових. Крім того, площини СМ можуть включати структури різних організаційних та функціональних складових. Окреслену модель можна уявити у вигляді чотиришарової сендвіч-моделі системи професійно-педагогічної підготовки студентів університетів, елементами якої є функціональні площини - множини пов'язаних між собою вузлів (об'єктів), упорядкованих за певними логічними правилами. Розроблена Н. Г. Сидорчук сендвіч-модель на основі виділення певних функціональних площин (підсистем) далі представлена у вигляді: зовнішньої або загальноєвропейської; внутрішньої або 
національної; структурно-змістової або інституціональної; локальної або прикладної. "Багатошарова модель" дає змогу відобразити глибинність структурної реформи європейської вищої школи на етапі переходу до суспільства знань, оскільки сама реформа як загальносистемне явище є багатошаровим процесом (циклом реформ) загальноєвропейського, національного (державного), інституціонального (вузівського) рівнів. Кожна з представлених оболонок має особливості цільового, змістового, прикладного характеру, які стали предметом дослідження науковця. Дослідником доведено ефективність запропонованої системи професійної освіти.

Компетентнісні професійно оріснтовані моделі підготовки майбутніх педагогів.

В. А. Ковальчук, виходячи із Закону України "Про вищу освіту" (2014 р.) та положення, що професійна компетентність учителя є сукупністю складових компетентностей (Н. В. Кузьміна), виявила нерозробленість у науковій літературі саме педагогічно-спеціалізованої компетентності в умовах варіативності освітньо-виховних систем. Останнє стало одним з головних завдань ії дослідження. Окреслена компетентність вміщує сукупність необхідних знань, умінь, навичок, ціннісних ставлень та досвіду творчої дослідницької діяльності, що забезпечують успішне виконання вчителем своєї професійної діяльності у визначених умовах, а також розглядається автором через набір компетенцій, які відображають специфічність і предметну спрямованість такої підготовки. Охарактеризуємо їх. Мотиваційно-ціннісна компетенція передбачає сформованість у майбутніх учителів професійних та особистих інтересів і потреб, позитивної мотивації у виборі професійної діяльності, ціннісних орієнтацій навчання, пов'язаних із специфікою професії учителя. Предметна компетенція у межах вивчення педагогічних дисциплін спрямована на засвоєння теоретичних знань про концепцію освітньо-виховних систем (сутність освітньо-виховної системи, розуміння іiі особливостей, етапів розвитку, умов функціонування, типології), методичних знань про особливості професійної діяльності, специфіку освітньо-виховного середовища конкретного закладу освіти. Технологічна компетенція передбачає оволодіння майбутніми вчителями необхідним комплексом професійних умінь, необхідними для реалізації професійної стратегії в умовах конкретного закладу з урахуванням специфіки його освітньовиховної системи. Інформаційно-дослідницька компетенція сприяє оволодінню студентами вміннями здійснювати науково-дослідницьку діяльність з учнями та розвивати здібності; здійснювати пошук, обробку, узагальнення та систематизацію необхідної інформації. Компетенція самопізнання $і$ самооцінки дає можливість на основі вивчення особистісних якостей формувати у студентів уміння самоактуалізації, самоконтролю і самооцінки у процесі професійної діяльності. Відповідно професійна підготовка майбутнього вчителя до роботи у різних освітньо-виховних системах розглядається як комплексний педагогічний процес формування професійної компетентності, ядром якої є педагогічно-спеціалізована компетентність майбутнього вчителя у визначених умовах [13].

Н. В. Яксою розроблено концептуальну модель професійної підготовки майбутніх учителів, що досліджує компетентність майбутніх учителів в організації полікультурної взаємодії суб'єктів освітнього простору та грунтується на методології загального, особливого, одиничного. Теоретичні засади моделі спираються на системний, професіографічний, діяльнісний, особистісно орієнтований, акмеологічний, аксіологічний, культурологічний, технологічний підходи. Окреслена модель реалізована у трьох площинах: 1) структурній (мета; суб'єкти; предмет їх спільної діяльності; засоби комунікацій); 2) процесуальній (цілемотиваційний, змістовий, операційно-діяльнісний, оцінно-результативний компоненти моделі); 3) аксіологічній (цінності професійної діяльності). У моделі визначено результат професійно-педагогічної підготовки майбутнього вчителя до міжкультурної взаємодії суб'єктів освітнього простору у вигляді сформованої готовності майбутнього педагога до цього виду діяльності та його компетентності в міжкультурній взаємодії суб'єктів освітнього простору. Автором виділено основні характеристики концепції полікультурної освіти: рухливість, мінливість, відкритість, здатність до діалогу, психокультурна адаптивність, толерантність. Ці ознаки реалізуються у контексті проблеми спілкування в освітньому процесі, яким присвячено роботи, пов'язані з теорією зв'язку і теорією інформації та досліджень у сфері комунікації. У цьому напрямі досліджуються: проблема субкультури молоді (традиції, цінності, системи відносин); ідеї продуктивності; когнітивний напрям сучасної персонології; теорія мультикультурної освіти. Такі підходи розширюють міжкультурну взаємодію суб'єктів освіти, розвивають полікультурний діалог, що сприяє зближенню представників різних етнічних та культурних груп [14].

О. С. Березюк створено цілісну систему етнопедагогічної підготовки майбутнього вчителя у контексті компетентнісного підходу. Актуальність компетентнісного підходу до етнопедагогічної обізнаності дітей та молоді зумовлена й українознавчою освітньою політикою. Саме об'єктивні потреби гуманізації освіти, іiї олюднення, об’єктивізація, народність стали підгрунтям перегляду ставлення до української етнопедагогіки, до цінностей світової цивілізації тощо. Ураховано, що етнопедагогічна компетентність особистості - це цілісний процес формування і розвитку у майбутніх учителів народознавчих, етнографічних, психолого-педагогічних, методичних знань, відповідних умінь, здібностей, цінностей, досвіду ініціативної діяльності. На цій основі визначено три основні аспекти 
етнопедагогічної професійної компетентності, a саме: змістовий проблемно-практичний i комунікативний. Кожен 3 них ураховує принцип полікультурності як загальнодержавну особливість інтелектуального простору України. Крім того дослідником виокремлено провідні аспекти етнопедагогічної компетентності: громадянський, етносоціальний, етнокультурологічний, етновалеологічний, фамілістичний. Громадянський напрям етнопедагогічної компетентності характеризує рівень національної свідомості, патріотизм особистості, повагу до рідного та інших народів світу, любов до рідної землі. Етносоиіальний напрям - це знання про народні традиції міжособистісних взаємин, етнічні уявлення про ідеальну модель особистості, якій притаманні типові риси етнічної спільності, ментальності народу. Етнокультурологічний напрям характеризує культурологічне світобачення особистості, уміння сприймати відображення реальності в народному мистецтві, готовність до самовдосконалення відповідно до опанування народними традиціями, до рис національного характеру. Етновалеологічний напрям передбачає оволодіння молоддю етнічним досвідом збереження та зміцнення свого здоров'я (фізичного, соматичного, психічного, духовного). Фамілістичний напрям грунтується на знаннях багатовікової історії розвитку родинного життя, це знання про практичний досвід українського народу щодо організації шлюбу та створення міцної здорової сім'ї. Отже, етнопедагогічна компетентність - це, передусім, результативно-діяльнісна характеристика народознавчої освіти, яскравий взірець культивування в молодої людини українознавчого спрямування, забезпечення органічного взаємозв'язку із сучасними принципами демократизації та европеїзму [15]. Відтак, узагальнення результатів наукового пошуку дозволяє обгрунтувати концептуальні положення полікультурної освіти та етнопедагогічної підготовки майбутнього вчителя зокрема, розробити концептуальні положення полікультурної педагогічної освіти суб'єктів освітнього простору.

\section{Концептуальна модель ступеневої підготовки майбутніх учителів.}

С. С. Вітвицькою запропоновано шляхи підвищення ефективності підготовки магістрів до педагогічної діяльності в умовах ступеневої освіти: забезпечення спадкоємності та наступності у підготовці педагогів різних освітньо-кваліфікаційних рівнів; оновлення змісту, методів підготовки студентів магістратури; встановлення доцільного співвідношення змістового та практично-діяльнісного компонентів педагогічної підготовки випускників класичних і педагогічних університетів відповідних освітньо-кваліфікаційних рівнів; спрямування навчально-виховного процесу на формування готовності майбутніх фахівців до інноваційної педагогічної діяльності та розвиток особистісних якостей;оволодіння особистісно орієнтованими технологіями навчання і виховання, організація проблемного навчання та творчого пошуку розв'язання проблем; забезпечення випереджувального характеру підготовки педагогічних кадрів [16].

О. Л. Шквир спроектовано концептуальну модель ступеневої підготовки майбутніх учителів початкових класів до проведення педагогічних досліджень, визначено відповідні педагогічні умови та експериментально перевірено їх ефективність. Авторська модель розглядається як комплекс взаємопов'язаних компонентів педагогічного процесу на кожному рівні вищої освіти, що забезпечує формування у студентів готовності до проведення педагогічних досліджень. Представлена модель вміщує цільовий, концептуальний, ціннісно-мотиваційний, змістовий, операційно-діяльнісний та результативний блоки підготовки. Ціннісно-мотиваційний блок передбачає формування ціннісного ставлення до педагогічної діяльності загалом і до дослідницької, зокрема, як іії провідної функції; вироблення у студентів позитивної мотивації до проведення педагогічних досліджень та особистісних якостей. Охарактеризовано провідні мотиви навчання (емоційно-спонукальні, перспективно-спонукальні та інтелектуально-спонукальні). Змістовий блок спрямований на розробку системи дослідницьких знань, конкретизацію сутності та змісту дослідницької діяльності вчителя початкових класів, розвиток педагогічного мислення. Операційно-діяльнісний блок передбачає оволодіння студентами дослідницькими діями, удосконалення способів проведення педагогічних досліджень, вироблення дослідницьких умінь та педагогічного досвіду. Основними етапами підготовки визначено початковий, бакалаврський, магістерський. Відповідно до принципу наступності на кожному етапі окреслено зміст, форми, методи, прийоми, технології навчання та форми науково-дослідної роботи. Результативний блок включає компоненти, критерії та рівні готовності до проведення педагогічних досліджень. О. Л. Шквир також охарактеризовано відповідні варіативні моделі ступеневої підготовки майбутніх учителів: професійно-практичну та професійно-теоретичну [17]. Їх ефективність доведена в процесі експерименту.

Висновки та перспективи подальшого дослідження проблеми. Результати аналізу діяльності Житомирської науково-педагогічної школи засвідчили про її вагомі здобутки на етапі концептуалізації наукових знань. Науковцями школи у межах досліджень на рівні докторських дисертацій вдалося розробити різноваріантні концептуальні моделі (когнітивні, системні, компетентнісні, ступеневі) професійної підготовки майбутніх учителів, які відображають діалектику загального особливого й часткового. На рівні загального обгрунтовано теоретико-методологічні засади професійної освіти, уточнено базові поняття дослідження, проаналізовано наукові підходи до професійної підготовки вчителя. На рівні особливого - виявлено специфіку такої підготовки різних категорій учителів. На рівні 
часткового - на кожному етапі професійної підготовки визначено та реалізовано відповідно науковому напряму дослідження зміст, форми, методи, прийоми, методики та технології навчання та науководослідної роботи. Зокрема, на цьому етапі охарактеризовано варіативні моделі ступеневої підготовки майбутніх учителів початкової школи до проведення педагогічних досліджень.

До перспектив подальших досліджень можна віднести такі проблеми: теоретико-методичні засади формування наукової компетентності майбутнього педагога; розвиток креативності майбутніх педагогів, готовності до наукового пошуку у процесі фахової та науково-дослідної діяльності; дослідження психолого-педагогічних умов якісної перебудови системи наукової освіти викладачів закладів вищої освіти, спрямованої на науковий та професійно-особистісний розвиток науково-педагогічних кадрів; подальша розробка інформаційно-методичного супроводу наукової освіти педагога-дослідника, забезпечення випереджувального характеру науково-педагогічної освіти.

\section{СПИСОК ВИКОРИСТАНИХ ДЖЕРЕЛ ТА ЛІТЕРАТУРИ}

1. Ярошевський М. Г. Логика розвития науки и научная школа / М. Г. Ярошевський // Школы в науке. - М. : Наука, 1977. - С. 7-97.

2. Вернадський В. И. Труды по истории науки в России / В. И. Вернадський. - М. : Наука, 1988

3. Наукова школа - центр професійної підготовки педагогічних кадрів : наук. збірник / за ред. проф. О. А. Дубасенюк. - Вид. 2-ге. - Житомир : Житомир. держ. пед. ун-т, 2005. - 418 с.

4. Дубасенюк О. А. Роль наукової школи у підготовці викладача-дослідника / О.А. Дубасенюк // Професійна освіта : педагогіка і психологія / за ред. Т. Левовицького, І. Вільщ, І. Зязюна, Н. Ничкало. - Ченстохова-Київ, 2008. - Вип. Х. - С. 195-203.

5. Житомирська науково-педагогічна школа "Професійно-педагогічна підготовка майбутніх учителів" : здобутки та перспективи : зб. наук. праць / авт. кол. О. А. Дубасенюк, О. Є.Антонова, С. С. Вітвицька та ін. ; за заг. ред. проф. О. А. Дубасенюк. - Житомир : Вид-во ЖДУ ім. І.Франка, 2009. - 432 с.

6. Дубасенюк О. А. Житомирська науково-педагогічна школа : історія, здобутки, перспективи / О. А. Дубасенюк // Становлення і розвиток науково-педагогічних шкіл : проблеми, досвід, перспективи : зб. наук. праць / за ред. В. Кременя, Т. Левовицького, ред. кол. : В. Г. Кременя, Т. Левовицького, І. А. Зязюн, П. Ю. Саух, Н. Г. Ничкало, О. А. Дубасенюк, Житомир, Вид-во ЖДУ ім. I Франка. 2012. - С. 114-148.

7. Дубасенюк О. А. Професійно-педагогічна освіта: методологія, теорія, практика : монографія / О. А. Дубасенюк. - Т. 2. - Житомир : Вид-во ЖДУ імені Івана Франка, 2015. - 376 с.

8. Михеев В. И. Моделирование и методы теории измерений в педагогике [текст]. - 3-е изд., стереотип. / В. И. Михеев. - М. : КомКнига, 2006. - 200 с.

9. Дубасенюк О. А. Професійно-педагогічні задачі: типологія та технологія розв'язання : [навч. посібник для студентів вищих навчальних закладів] / О. А. Дубасенюк, О. В. Вознюк. - Житомир : Вид-во ЖДУ ім. Імені Франка, 2010. - 272 с. - С. 100-103.

10. Коновальчук I. І. Теорія і технологія реалізації інновацій у загальноосвітніх навчальних закладах: [монографія] / І. І. Коновальчук. - Житомир : Вид-во ЖДУ ім. І. Франка, 2014. - 464 с.

11. Антонова О. С. Теоретичні та методичні засади навчання педагогічно обдарованих студентів : [монографія]/ О. Є. Антонова. - Житомир : Вид-во ЖДУ ім. І. Франка, 2007. - 460 с.

12. Сидорчук Н. Г. Професійно-педагогічна підготовка студентів університетів у контексті єдиного європейського освітнього простору : історико-педагогічний аспект : [монографія] / Н. Г. Сидорчук; за заг. ред. О. А. Дубасенюк. - Житомир : Вид-во ЖДУ ім. І. Франка, 2014. - 608 с.

13. Ковальчук В.А. Формування у майбутніх вчителів професійної компетентності здійснювати педагогічну діяльність в умовах варіативності освітньо-виховних систем // Проблеми освіти: збірник наукових праць. Вінниця-Київ, 2015. - № 84. - Спецвипуск. - 110 с. - С. 41-45.

14. Якса Н. В. Підготовка майбутніх учителів до полікультурної взаємодії із суб'єктами освітнього простору / Н. В. Якса // Педагогічний процес : теорія і практика : Наукові записки. - К. : Вид-во "ЕКМО", 2006. C. $198-207$.

15. Березюк О. С. Методичні засади формування етнокультурної компетентності особистості / О. С. Березюк // Освітологічний дискурс: електронне наукове фахове видання. - 2015. - № 3 (11). - С. 13-21.

16. Вітвицька С. С. Теоретичні і методичні засади педагогічної підготовки магістрів в умовах ступеневої освіти : [монографія] / С. С. Вітвицька. - Житомир: "Полісся", 2015. - 416 с.

17. Шквир О. Л. Перевірка ефективності впровадження моделі ступеневої підготовки майбутніх учителів початкових класів до проведення педагогічних досліджень / О. Л. Шквир // Педагогіка формування творчої особистості у вищій і загальноосвітній школах. Т. І. Сущенко, гол. ред. : зб. наук. пр. Запоріжжя : КПУ. 2017. - Вип. 52 (105). - С. 367-374.

\section{REFERENCES (TRANSLATED \& TRANSLITERATED)}

1. Yaroshevs'kii M. G. Logika rozvitiia nauki i nauchnaia shkola [The Logic of the Development of Science and the Scientific School] / M. G. Yaroshevs'kii // Shkoly v nauke [Schools in Science]. - M. : Nauka, 1977. - S. 7-97.

2. Vernads'kii V. I. Trudy po istorii nauki $v$ Rossii [Proceedings on the History of Science in Russia] / V. I. Vernads'kii. - M. : Nauka, 1988.

3. Naukova shkola - tsentr profesiinoi pidgotovky pedagogichnykh kadriv [Scientific School is a Center for Professional Training of Pedagogical Staff] : [nauk. zbirnyk] / za red. prof. O. A. Dubasenyuk. - Vyd. 2-ge. Zhytomyr : Zhytomy`r. derzh. ped. un-t, 2005. $-418 \mathrm{~s}$. 
4. Dubasenyuk O. A. Rol' naukovoi shkoly u pidgotovtsi vykladacha-doslidnyka [The Role of a Scientific School in the Training of a Teacher-Researcher] / O. A. Dubaseniuk // Profesiina osvita : pedagogika i psykhologiia [Professional Education: Pedagogy and Psychology] ; ed. T. Levovitsky, I. Wilchev, I. Zyazyun, N. Nichkalo] / za red. T. Levovytskogo, I. Vilshh, I. Zyazyuna, N. Nychkalo. - Chenstokhova-Kyiv, 2008. - Vyp. X. - S. 195-203.

5. Zhytomyrs'ka naukovo-pedagogichna shkola "Profesiino-pedagogichna pidgotovka maibutnikh uchyteliv": zdobutky ta perspektyvy : zb. nauk. prats' [Zhytomyr Scientific and Pedagogical School "Professional and Teacher Training for Future Teachers": Achievements and Prospects] / avt. kol. O. A. Dubasenyuk, O. Ye. Antonova, S. S. Vitvytska ta in. ; za zag. red. prof. O. A. Dubasenyuk. - Zhytomyr : Vyd-vo ZhDU im. I. Franka, 2009. $432 \mathrm{~s}$.

6. Dubasenyuk O.A. Zhytomyrs'ka naukovo-pedagogichna shkola : istoriia, zdobutky, perspektyvy [Zhytomyr Scientific-Pedagogical School : History, Achievements, Prospects] / O. A. Dubasenyuk // Stanovlennya i rozvytok naukovo-pedagogichnykh shkil : problemy, dosvid, perspektyvy [Formation and Development of Scientific and Pedagogical Schools: Problems, Experience, Perspectives] : zb. nauk. prats' / za red. V. Kremenia, T. Levovytskogo, red. kol. : V. G. Kremenya, T. Levovytskogo, I. A. Zyazyun, P. Yu. Saukh, N. G. Nychkalo, O. A. Dubasenyuk. Zhytomyr, Vyd-vo ZhDU im. I. Franka. 2012. - S. 114-148.

7. O. A. Dubasenyuk Profesiino-pedagogichna osvita : metodologiia, teoriia, praktyka [Professional-Pedagogical Education: Methodology, Theory, Practice] : [monografiia] / O. A. Dubasenyuk. - T. 2. - Zhytomyr : Vyd-vo ZhDU imeni Ivana Franka, 2015. - $376 \mathrm{~s}$.

8. Miheev V. I. Modelirovanie i metody teorii izmerenii v pedagogike [Modeling and Methods of Measurement Theory In Pedagogy] [tekst]: - 3-e izd., stereotip. / V. I. Miheev. - M. : KomKniga, 2006. - 200 s.

9. Dubasenyuk O. A. Profesiino-pedagogichni zadachi: typologiia ta texnologiia rozviazannia [ProfessionalPedagogical Tasks: Typology and Technology of the Decision] : [navch. posibnyk dlia studentiv vyshhykh navchal'nykh zakladiv] / O. A. Dubasenyuk, O. V. Voznyuk. - Zhytomyr : Vyd-vo ZhDU im. Imeni Franka, 2010. 272 s. - S. 100-103.

10. Konovalchuk I. I. Teoriia i tekhnologiia realizatsii innovatsii u zagal'noosvitnikh navchal'nykh zakladakh [Theory and Technology of Innovation Implementation in General Educational Institutions]: [monografiia] / I. I. Konovalchuk. - Zhytomyr : Vyd-vo ZhDU im. I. Franka, 2014. - 464 s.

11. Antonova O. Ye. Teoretychni ta metodychni zasady navchanni pedagogichno obdarovanykh udentiv [Theoretical and Methodical Principles of Teaching Pedagogically Gifted Students] : [monografiia] / O. Ye. Antonova. Zhytomyr : Vyd-vo ZhDU im. I. Franka, 2007. - 460 s.

12. Sydorchuk N. G. Profesiino-pedagogichna pidgotovka studentiv universytetiv u konteksti yedynogo yevropeis'kogo osvitniogo prostoru : istoryko-pedagogichnyi aspekt [Vocational-Pedagogical Preparation of University Students in the Context of a Single European Educational Space: Historical and Pedagogical Aspect]: [monografiia] / N. G. Sydorchuk ; za zag. red. O. A. Dubasenyuk. - Zhytomyr : Vyd-vo ZhDU im. I. Franka, 2014. - 608 s.

13. Kovalchuk V.A. Formuvannia u maibutnikh vchyteliv profesiinoi kompetentnosti zdiisnyuvaty pedagogichnu diyal'nist' v umovakh variatyvnosti osvitnio-vykhovnykh system [Formation of Future Teachers of Professional Competence to Carry out Pedagogical Activity in Conditions of Variability of Educational-Educational Systems // Problemy osvity [Problems of Education] : zbirnyk naukovykh prats'. - Vinnytsia-Kyiv, 2015. - № 84. - Spets vypusk. $-110 \mathrm{~s}$.

14. Yaksa N. V. Pidgotovka maibutnikh uchyteliv do polikul'turnoi vzayemodii iz subiektamy osvitniogo prostoru / N. V. Yaksa // Pedagogichnyi proces : teoriia i praktyka [Preparation of Future Teachers for Multicultural Interaction with Subiects of Educational Space] / N. V. Yaksa // Pedagogical Process: Theory and Practic] : naukovi zapysky. - K. : Vyd-vo "EKMO", 2006. - S. 198-207.

15. Berezyuk O. S. Metodychni zasady formuvannia etnokul'turnoi kompetentnosti osobystosti [Methodical Principles of Formation of Ethnocultural Competence of Personality] / O. S. Berezyuk // Osvitologichnyi dyskurs [Educational Discourse] : [elektronne naukove fakhove vydannia] / O. S. Berezyuk. -2015. -3 (11). - S. 13-21.

16. Vitvytska S. S. Teoretychni i metodychni zasady pedagogichnoyi pidgotovky magistriv v umovakh stupenevoi osvity [Theoretical and Methodical Principles of Pedagogical Preparation of Masters in Conditions of Degree Education] : [monografiia] / S. S. Vitvytska. - Zhytomyr : "Polissya", 2015. - $416 \mathrm{~s}$.

17. Shkvyr O. L. Perevirka efektyvnosti vprovadzhennia modeli stupenevoi pidgotovky maibutnikh uchyteliv pochatkovykh klasiv do provedennia pedagogichnykh doslidzhen' [Pedagogy of the Formation of a Creative Person in Higher and Secondary Schools] / O. L. Shkvyr // Pedagogika formuvannia tvorchoi osobystosti u vyshhii i zagal'noosvitnii shkolakh [Verification of the Effectiveness of Implementation of the Model of Step-By-Step Training for Future Teachers of Elementary School to Conducting Pedagogical Researches] / O. L. Shkvyr // T. I. Sushhenko, gol. red. : zb. nauk. pr. - Zaporizhzhia : KPU. 2017. - Vyp. 52 (105). - S. 367-374.

\section{Дубасенюк А. А. Концептуальные модели профессионально-педагогической подготовки будущих педагогов, реализованные в деятельности Житомирской научной иколь.}

В статье обоснована роль научных школ в системе высшего образования, проанализирована их сущьность, выделены признаки научной школь. Представлены результаты 30-летней деятельности Житомирской научно-педагогической школь на этапе конщептуализачии научных знаний. $B$ деятельности школы реализованы следующие принципы: научности, системности, преемственности, непрерывности, активности, интегративности. Представлены разнообразные концептуальные модели профессионально-педагогической подготовки будущего учителя (когнитивная, системная, 
компетентностная, ступенчатая), разработанные в рамках Житомирской научной школь, проанализированы их результативность и перспективность.

Ключевые слова: научная школа, Житомирская научно-педагогическая школа, концептуальные модели исследования, профессионально-педагогическая подготовка.

\section{Dubaseniuk O. A. Conceptual Models of Vocational and Pedagogical Training of Prospective Teachers, Realized in the Activity of Zhytomyr Scientific School.}

The article states that in the conditions of globalization transformations, modern science is rapidly developing, new promising directions and specialties are constantly being opened up, and the volume of scientific publications grows. In the process of accelerated development of sciences, a significant role is played by scientific schools. However, the current social situation is characterized by a decline in the public interest in science, the loss of prestige of scientific knowledge and the outflow of promising scientific staff abroad and in other fields of activity. Such a condition requires an increase in attention to the problems of scientific education, the development of scientific schools. The research presents the results of the 30-year activity of Zhytomyr scientific and pedagogical school at the stage of conceptualization of knowledge in the form of developed conceptual models of vocational and pedagogical preparation of the future teacher in the unity of several aspects of its application, namely the epistemological, according to which the outlined model appears as an element of the process of cognition of pedagogical phenomena; general methodological, since there is a need to assess the relationship and relationship between the components of vocational education and the whole system of vocational education. The main methods of research include: analysis, synthesis, modelling, systematization, classification, comparison, etc. The conducted analysis of the Zhytomyr scientific and pedagogical school enabled to distinguish conceptual models of vocational and pedagogical training of future teachers, based on its purpose, content, structure, methods, result. The conducted studies have shown the significant achievements of the school's scientists at the stage of conceptualization of scientific knowledge. Teachers-researchers, within the framework of the performed research at the level of doctoral theses, managed to develop a variety of conceptual models (cognitive, systemic, competence, step-by-step) for the training of future teachers, reflecting the dialectic of the general and special. The perspective directions of further research include: substantiation of theoretical and methodical principles of forming the scientific competence of the future teacher; research of psychological and pedagogical conditions of qualitative transformation of the system of scientific education of teachers of institutions of higher education.

Key words: scientific school, Zhytomyr scientific and pedagogical school, conceptual models of research, vocational and pedagogical training. 